\title{
Student's concept ability of Newton's law based on verbal and visual test
}

\author{
N D Setyani ${ }^{1 *}$, $^{*}{ }^{2}{ }^{2}$ Suparmi $^{3}$, J Handhika $^{5}$ \\ ${ }^{1}$ Science Education, Postgraduate Program, Universitas Sebelas Maret, Surakarta, Indonesia \\ ${ }^{2,3}$ Lectures of Universitas Sebelas Maret, Surakarta, Indonesia \\ ${ }^{4}$ Lectures of IKIP PGRI Madiun, Indonesia \\ *Email : nitadepitsetyani@gmail.com
}

\begin{abstract}
Newton's law is a foundamental concept that needs to be studied and understood correctly. Concept presentation in different representation will help the student to understand the concept that being learned. Student's ability to present Newton's law in different representation indicate the quality of student's concept ability. This research aims to describe student's concept ability of Newton's laws based on the student's ability of verbal and visual (pictorial and graphical) problem solving. The method of this research is qualitative with the sample of 71 students of physics education from IKIP PGRI Madiun (14 students) and Sebelas Maret University (57 students). The instrument used in this research were conceptual test and interview. The result showed that more student provide incorrect answer to the physics conceptual problem. Percentage of the incorrect answer for First Newton's law problem is $69 \%$, Second Newton's law problem is $71 \%$, and Third Newton's law problem is $76 \%$. The students do not understand the language of physics correctly, they undergo incorrect physics concept, and so they only understand few physics concept of Newton's law.
\end{abstract}

\section{Introduction}

Physics is a subject matter that is difficult to be understood by mostly students. In learning physics, besides we have to be capable of physics concept, the students also to have the mathematical capability, logic, and intuition language correctly. Students have to use mathematical, symbols and intuition language influence that construction of concept correctly [1]. Representation is a description of the relationship between objects and symbols [2]. Multiple representations refers to the practice of re-representing the same concept through different forms, including verbal, graphic and numerical modes, as well as repeated student [3]. Concept presentation in different representation will help the students on ability of concept that being learnt. For example, the verbal explanation can be easily understood if accompanied ilustration or sceme. Multirepresentation has three main functions as a complementary roles, constrain interpretation, and construct deeper understanding [4,5]. By those statements, in learning physics it is needed to present the physics concept in multirepresentation form. Student's ability to present the physics concept in different representation indicate the quality of student's concept ability. 
Dynamics of motion is a part of physics that learning about motion and the force that caused the motion. The principle of Newtonian dynamics is an important concept that needs to be studied in addition to energy [6]. Newton's law of dynamics concept can be easily understood if it is presentation in different representation. Based on another research, in the kinematics and dynamics lessons, students have difficulty in represent visual and symbols information. Representation difference between the two can bring cognitive conflict for students [7].

This research aims is to describe the student's concept ability of Newton's law based on the student's ability of verbal and visual (illustration and graphical) problem solving. The concept ability is referred to incorrect answer by the students.

\section{Methods of Research}

The method of this research is qualitative method with the sample of 71 students of physics education from IKIP PGRI Madiun (14 students) and Sebelas Maret University (57 students). The subject of research is a students in physics education that have taken the course of basic physics I and mechanics. The data was collected using multiple choice conceptual test. The conceptual test are being adapted from FCI [8] and R-FCI [9]. The result of data is reinforced by the interview.

\section{Result and Discussion}

The results showed that more students have the incorrect answer about Newton's Law problems. Their incorrect answer is being shown in figure 1 and figure 2 .

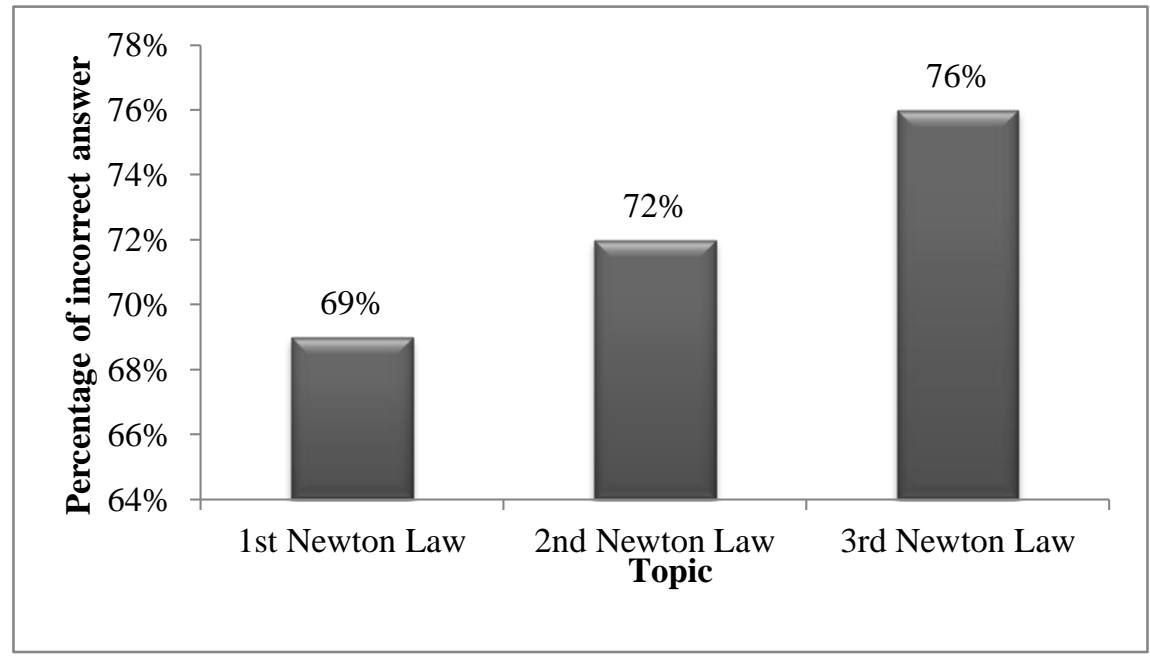

Figure 1. Percentage of the student's incorrect answer 


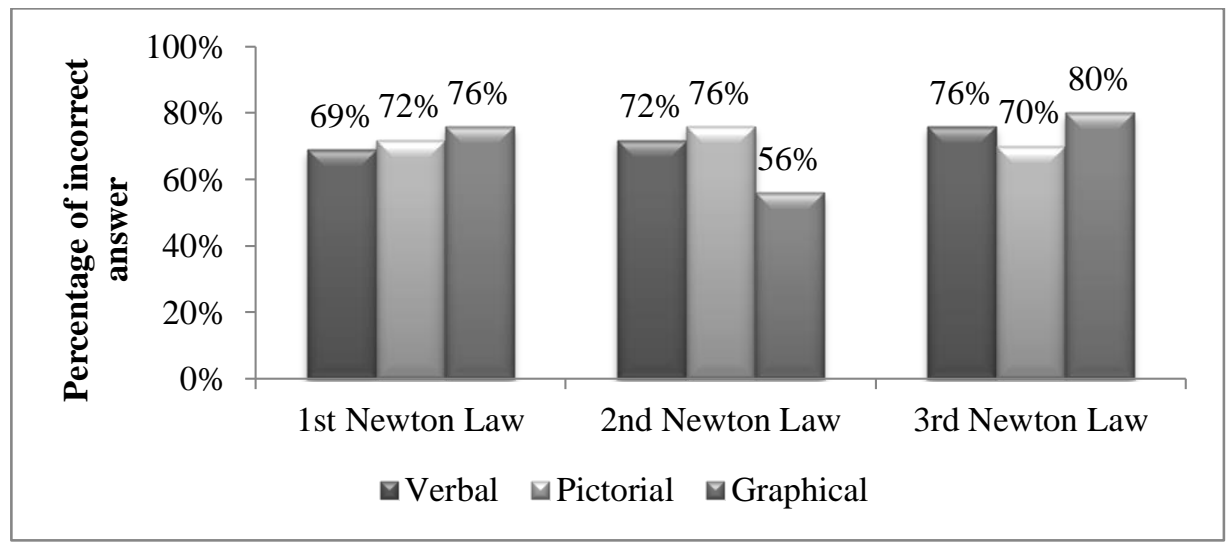

Figure 2. Percentage of the students that give incorrect answer of verbal and visual problem

From figure 1, can be seen that the more students have the incorrect answer of Newton's Law problems. The highest percentage of incorrect answer is on $3^{\text {rd }}$ Newton's Law problem, $76 \%$. Meanwhile, $1^{\text {st }}$ Newton's Law problem is $69 \%$ and $2^{\text {nd }}$ Newton's Law problem is $72 \%$.

\subsection{First Newton's Law}

$1^{\text {st }}$ Newton's Law has the lowest incorrect answer (69\%). The highest percentage of incorrect answer is on graphical representation problem (fig 2). The incorrect answer profile is shown in table 1.

Table 1.The incorrect answer on $1^{\text {st }}$ Newton's Law problem.

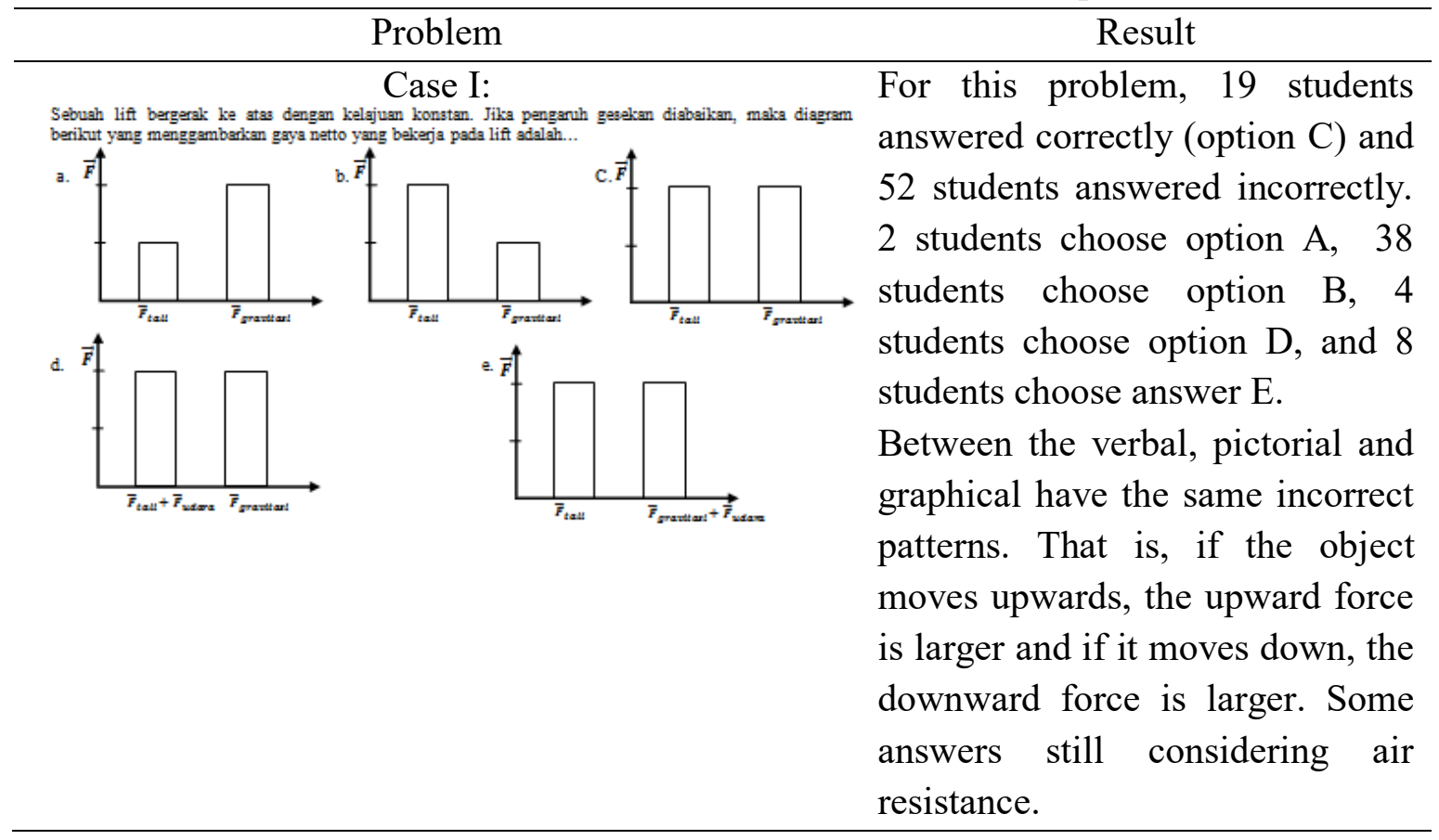

Interview result with the student for case 1:

Researcher : Explain your answer on number 1! Are you sure with your answer?

Student : I'm sure, Miss. 
Researcher : Try to explain!

Student : My answer is B, because the elevator moves up. If the object moves up, it means the more force is up. If it moves down, the more force is down.

Interview result for another incorrect answer:

Researcher : What's your choice for number 5?

Student : Since the upper force of string is the same as sum of force weight with air resistance.

Researcher : When you are solving number 5, what are all terms that you know?

Student : Force of string T, a mass that means it has $\mathrm{W}$ down, then gravitation. After that, due to friction force is ignored, it means the upper force is the same with the lower force, it's the sum of weight force and air resistance to the down below.

Based on the data and interview result, it shows that the students have incorrect understanding of intuition to understand the problem. The students don't understand the meaning of constant motion and ignored air resistance force. Suitable with $1^{\text {st }}$ Newton's Law, if the object constantly moves, the resultant of force is zero. So, the problem in case I, the tension and gravitational force have sama value since the lift have constant speed. Tension force that is exerted by rope to the object in upward direction. The gravitational force is a force that is exerted by earth to the object in downward direction. But the perception of the more students is that the lift experience have the acceleration.

\subsection{Second Newton's Law}

$2^{\text {nd }}$ Newton's Law has the incorrect answer $72 \%$ (fig 1). The highest percentage of incorrect answer is on pictorial representation. The profile of incorrect answer is shown in table 2.

Table 2. The incorrect answer in $2^{\text {nd }}$ Newton's Law problem

\begin{tabular}{|c|c|}
\hline Problem & Result \\
\hline Case II & In the case II, 16 students \\
\hline $\begin{array}{l}\text { Sebuah roket yang mesinnya mati sedang melayang di angkasa dan bergerak dari titik } \\
\text { "a" ke titik " } \mathrm{b} \text { ". Roket tidak terpengaruh gaya luar. Pada posisi " } \mathrm{b} \text { ", mesin roket } \\
\text { dihidupkan untuk memperoleh dorongan konstan (gaya pada roket). Dorongan pada } \\
\text { roket tersebut dipertahankan oleh roket sampai roket mencapai titik "c" di ruang } \\
\text { angkasa. Seperti pada gambar berikut: }\end{array}$ & $\begin{array}{l}\text { answered correctly (option B) and } \\
45 \text { students answered incorrectly, } \\
\text { with the detail of option A(18 } \\
\text { students), C( } 4 \text { students), D (35 } \\
\text { students), E( } 2 \text { students). }\end{array}$ \\
\hline $\begin{array}{l}\text { Kecepatan roket ketika bergerak dari titik "b" menuju "c" adalah... } \\
\text { a. Konstan } \\
\text { b. Semakin meningkat } \\
\text { c. Semakin menurun } \\
\text { d. Meningkat sesaat kemudian konstan setelahnya } \\
\text { e. Konstan sesaat kemudian menurun setelahnya }\end{array}$ & \\
\hline
\end{tabular}




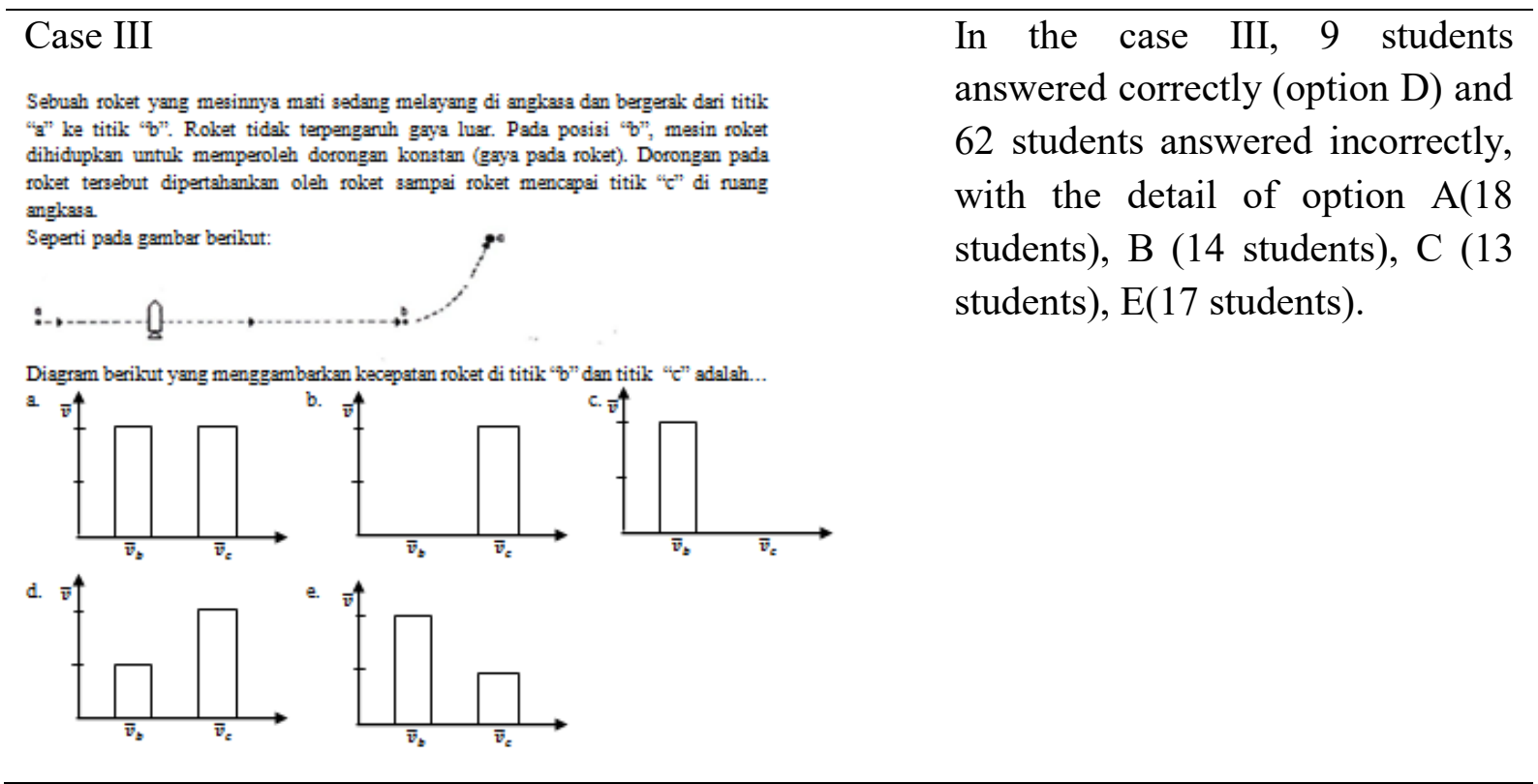

Students' answer shows that the students undergo incorrect concept about the effect of constant force that will have outcome constant acceleration with velocity increase. The increase of the velocity of unit time is conctant, so that the motion is uniform linear motion. The interview shows the students assume when nothing force that works on rocket, it means the object has no velocity. Result of the interview is:

Researcher : What's the number of Newton's Law about the rocket?

Student : That's the second Newton's Law. Because there is no velocity of rocket from $\mathrm{A}$ to $\mathrm{B}$, then it has a velocity from $\mathrm{B}$ to $\mathrm{C}$, and from $\mathrm{B}$ to $\mathrm{C}$ the velocity is increase.

Students can mention content and equation of $2^{\text {nd }}$ Newton's Law, however when they are faced to solve the problem, they still have the difficulties. Capable the partial concept will affect student's capability to solve Newton's Law conceptual problem. That's why, it's needed the deeper concept comprehension for the students to solve all of the problems of physics.

\subsection{Third Newton's Law}

$3^{\text {rd }}$ Newton's Law has the biggest level incorrect answer than another both (fig 1). Profile of incorrect answer is shown in table 3. 
Table 3. The incorrect answer in $3^{\text {rd }}$ Newton's Law problem

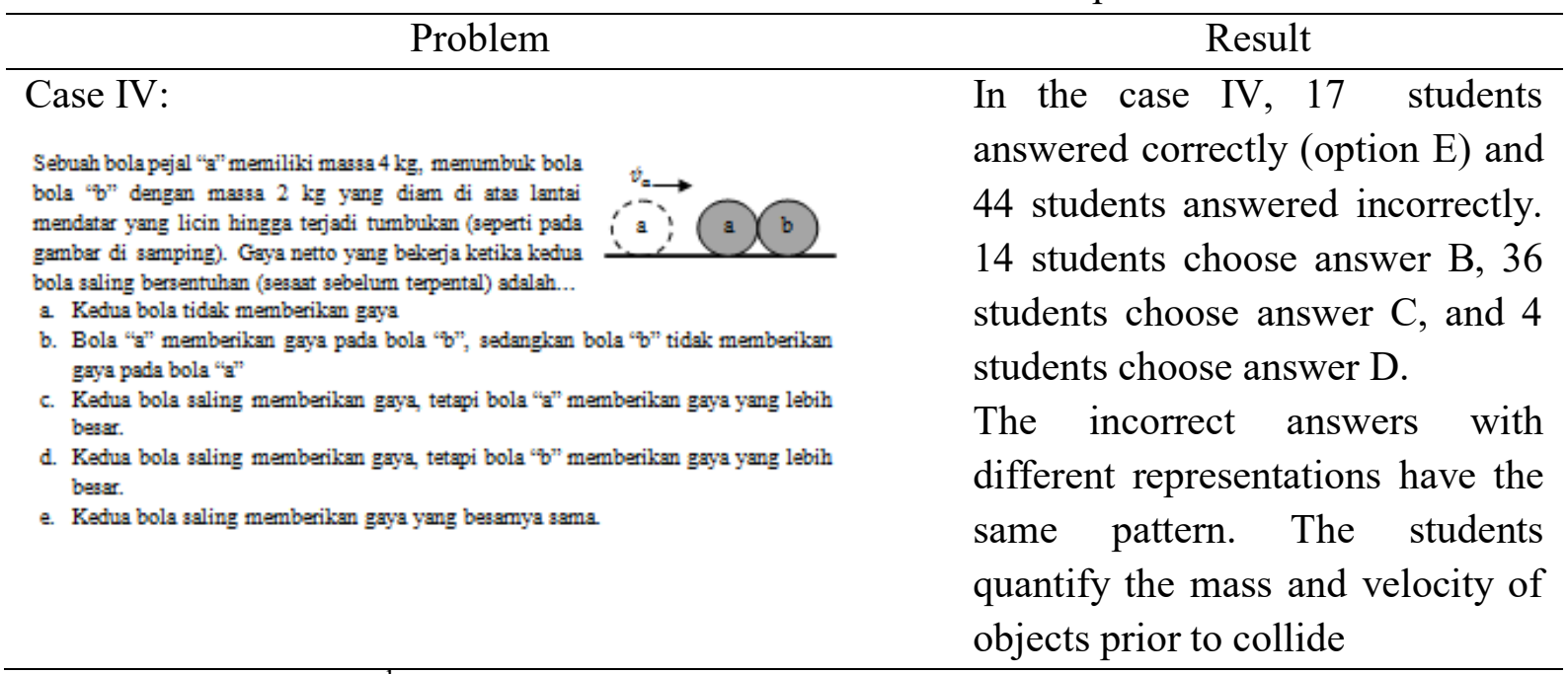

In accomplishing $3^{\text {rd }}$ Newton's Law problems, students assume that if two objects are in contact each other, the force that works on both objects are still being influenced by mass and object's velocity when they collide.

Result of interview such as:

Researcher : For problem number 8, what's your answer?

Student $\quad: F_{a b}$ is bigger than $F_{b a}$. The truck has bigger mass. Then, the truck brake so there is the force. From behind, there is a pushing from the car, with car's mass less than the truck. Car's velocity is increase. So, there is a force influence. Force that exerted by the car to the truck is bigger than force exerted by the truck to the car.

Researcher : What's factor that affects the more car's force?

Student : The mass, Miss. Car's mass is less than the truck. So, when the car is pushing truck, it needs the more force.

Researcher : Any other factor?

Student : Mass and velocity, Miss. Car's velocity is driven increase, so the force that exerted by the car to the truck also increase.

Student perceptions affected student conception [6]. The incorrect perception by the students affected the incorrect conception. Students' perception is the object which has the big mass or fast velocity will give effect the more force. According to the $3 \mathrm{rd}$ Newton's Law, when two objects collide, they will give the same force each other, by the opposite direction The formula is $\vec{F}_{\text {action }}=-\vec{F}_{\text {reaction. }}$. To solve this concept error is to make an experiment activity to prove the amount of force that works while both objects are in contact.

From this discussion, the students have the error in accomplishing multirepresentation problem due to still having understand partial concept, they were not understand the physics language correctly, incorrect in using intuition, they undergo incorrect concept, and student's habit of learning physics activity which tend to 
memorize mathematical equation without emphasize on concept comprehension, strategy to give an opinion in verbal, or the other representation appearance.

This result is also supported by result of interview such as:

Researcher : Do you still have any difficulties to determine Newton's Law that being used?

Student : No, Miss. The important part is the problem has in formulation way, not the comprehension like this. Because I prefer mathematics to a reasoning.

Mathematical capability is more dominant than student's perception, so it caused concept error. Integration between the mathematical capability and physics is quite important to decrease concept error [6]. Based on another research, the difficulties with graphical and functional representations were due to students' inability to apply mathematical knowledge into physics contexts [10].

In learning physics, it is needed to present the physics concept in multirepresentation form. Student's ability to present the physics concept in different representation indicate the quality of student's concept ability.

\section{Conclusion}

Based on result of research and discussion, the student's incorrect answer in accomplishing multi-representation problem in Newton's Law problem is still high. The average incorrect answer is still over 50\%. The $3^{\text {rd }}$ Newton's Law problem is the highest percentage of incorrect answer, that is $76 \%$ (fig1). The incorrect in determining the answer is caused by the students still having understand the partial concept, they were not understand the physics language correctly, incorrect in using intuition, they undergo incorrect concept, and student's habit in learning physics activity that tend to memorize mathematical equation without emphasizing the other representations.

\section{Acknowledgement}

The writer said thanks to all of the students of IKIP PGRI Madiun, Sebelas Maret University, Surakarta, and Hibah Riset Mandatory (RM-UNS) with contract number 632/UN27.21/LT/2016.

\section{References}

[1] Handhika, J., Cari, Suparmi \& Sunarno, W. 2015a. External Representation to Overcome Misconception in Physics. International Conference on Mathematics, Science, and Education. ICMSE 2015: 34-37.

[2] Hwang W. Y., Chen N. S., Dung J. J., \& Yang Y. L. 2007. Multiple Representation Skills and Creativity Effects on Mathematical Problem Solving using a Multimedia Whiteboard. System Educational Technology \& Society, 10(2), 191-212.

[3] Waldrip B., Prain V. dan Carolan J. 2006. Learning Junior Secondary Science through Multi Modal Representation. Electronic Journal of Science 
Educational. Retreived from http://ejse.southwestern.edu

[4] Ainsworth, S. 1999. The Functions of Multiple Representations. Computers \& Education, 33, 131-152

[5] Ainsworth, S. 2006. DeFT: A Conceptual Framework For Considering Learning With Multiple Representations. Learning and Instruction, 16, 183-198

[6] Handhika, J., Cari, Suparmi \& Sunarno, W. 2015b. Student Conception and Perception of Newton's Law. Proceedings of International Seminar on Mathematics, Science, and Computer Science Education. AIP Conference Proceeding.

[7] Lee G. \& Yi J. 2013. Where cognitive conflict arises from?: the structure of creating cognitive conflict. International Journal of Science and Mathematics Education. 11: 601-623

[8] Hestenes, D., Wells, M., dan Swackhamer, G. 1992. Force Concept Inventory. The Physics Teacher. 30. 141-158

[9] Nieminen P, Savinainen A, and Viiri J. 2010. Force Concept Inventory-based Multiple-choice Test for Investigating Students' Representational Consistency. Phys. Rev. ST Physics Ed. Research. 6, 020109.

[10] Nguyen, D. H., Rebello, N. S. 2007. Students' Difficulties with Multiple Representations in Introductory Mechanics. Department of Physics, Kansas States University. 